\title{
The Prejudice of Bajau: From Own and Others Ethnic Perspective: A Preliminary Study in Sabah
}

\author{
Lailawati Binti Madlan, Chua Bee Seok, Jasmin Adela Mutang, Shamsul Amri Baharudin, and Ho \\ Cheah Joo
}

\begin{abstract}
The purpose of the study is to identify prejudices among government and private worker toward the ethnic of Bajau in Malaysia, especially in Sabah state. A total of 22 workers from government and private agency were invited to join this study. In-depth interview had been used to investigate perception of Bajau towards own ethnic and perception of others ethnic toward Bajau. From analysis, ethnic groups identify themselves according three major aspects, which are 1) attitude and behavior, 2) physical and appearance, 3) culture. The conclusion from these research, the understanding from others ethnic groups toward Bajau is on the lesser side, but there are some of the factors that match the perception of Bajau toward themselves, such as Bajau is or rude natured. This might be due to the less understanding from others ethnic or the disappearing traditional culture of Bajau.
\end{abstract}

Index Terms-Prejudice, Bajau ethnic, government, private agency.

\section{INTRODUCTION}

The One Malaysia concept was introduced by Malaysian prime minister Dato Sri Najib Tun Abdul Razak. This concept promotes the unity among Malaysian of all races. Malaysia is built up by multi-races and these races are able to live under the same roof. However, Malaysia had been gone through ethnic crisis decades ago at 1969, also known as the tragedy of May 13. The tragedy involved 2 main races in Malaysia, which is Malay and Chinese and this tragedy had sacrificed many lives. This tragedy spurred the government to built up an organization, called Jabatan Perpaduan Negara dan Integrasi Nasional, in order to rebuild the understanding and harmony among each races, religion and culture. The harmony among each race is very important in order to stabilize the Malaysian society.

1Malaysia concept caters the needs of all sector of the plural society and to ensure equal distribution of wealth between racial groups, between states and federal. Integrity on the part of the government and the public sector is one matter. The managing of all spectrums of unity (not just racial) is to be given proper thinking. In order to move Malaysia towards a better society, identity and future hence unity and

Manuscript received September 13, 2013; revised November 21, 2013. This work was support by LRGS Grant UMS/SPKS 6.7.1/800-3/2/3 with tittles Stereotype, Prejudice and Discrimination among Ethnicity in Sabah.

Lailawati Madlan, Chua Bee Seok, Jasmin Adela Mutang, and Ho Cheah Joo are with Psychology and Social Health Research Unit, School of Psychology, Universiti Malaysia Sabah, Malaysia (e-mail: laila@ums.edu.my; chuabs@ums.edu.my; jasmine@ums.edu.my; hocj14@gmail.com).

Shamsul Amri Baharudin is with Director Institute of Ethnic Studies (KITA), Universiti Kebangsaan Malaysia (e-mail: abshamsul@gmail.com). integration should promote co-operation between race, beliefs and region as one Malaysia, not as Sarawakian or Sabahan. The trust and aspiration of the people that 1Malaysia will bring about a greater nation must not be hampered. Therefore, the government will have to deliver on all its promises. The concept unveiled is a guiding principle to build a united and progressive nation, and to inculcate the spirit and values of togetherness and sense of belongings, regardless of race, religion and creed.

Although this concept has been promoted, but it is not guaranteed for Malaysian harmonies for long term. Sometime people doesn't see the small things but it's can be a trigger for sensitive issue in our countries. Zahara Aziz and friends [1] conducted a research about prejudice at 9 areas in Selangor state. The result shows that the tolerance between the races is at the moderate stage. Chinese and Indian kept moving apart from each other between the years of 1993 to 2007. The findings also concluded that the situation of Malay with Chinese and Indian did not change much in terms of tolerance. According to the research, the factors that contribute to the deterioration of ethnic solidarity were influenced by economic and political issues.

Although the government implemented the New Economic Policy (NEP) in which the policy is intended to address the economic imbalance between the various races in Malaysia, but it did not helped much. This is attributed by the notion that the control of the economy is still monopolized by certain group of people even though the economy remained at a high pace. The unbalance of wealth distribution will bring about negative economy impact such as poverty especially for the rural indigenous farmers as well as non-indigenous ethnic groups who live in rural areas. The causes of this scenario relates to the industrial, business and corporate sector that mostly dominated by Chinese and foreigners.

Sabah is one of the states in Malaysia that is privileged to have a society of diverse ethnicity. Sabah sits at the tip of Borneo, the world's third largest island. It's Coastline of $1,440 \mathrm{~km}$ washed by the sea South China Sea on the West and Sulu Sea and Celebs Sea on the East. The population of about 2 million comprises over 34 different races speaking over 80 local dialects. The beautiful thing is all these diverse ethnic groups live together harmoniously while at the same time preserving their own culture, traditions, festivals and customs, to make Sabah a multicultural exotic experience unlike any other. There are about 34 ethnic groups in Sabah. However, out of the total there are five major ethnic groups in Sabah, which are Kadazandusun, Bajau, Murut, Chinese and Melayu Brunei. This study will only cover the ethnic of Bajau. This ethnic group is located in parts of the Sabah state, such as 
Kota Belud, Tuaran, Papar and Semporna.

The Bajau is an indigenous ethnic group of Maritime Southeast Asia, making up $13.4 \%$ of the total population of Sabah, the 2nd largest ethnic group in the state. Like the term "Kadazandusun", "Bajau" is a collective term, used to describe several closely-related indigenous groups. These Bajau groups also blend culturally with the "Sama" groups into what is most properly called the "Sama-Bajau" people. Historically, the term "Sama" was used to describe the more land-oriented and settled Sama-Bajau groups, while "Bajau" was used to describe the more sea-oriented, boat-dwelling, nomadic groups. Even these distinctions are fading as the majority of Bajaus have long since abandoned boat-living, most for Sama-style piling houses in the coastal shallows. Today, the greatest feature distinguishing the "Bajau" from the "Sama" is their poverty.

The Sama-Bajau peoples speak some 10 languages of the Sama-Bajau subgroup of the Western Malayo-Polynesian language family. Many Bajaus of the east coast retain their seaborne lifestyle and as such, are sometimes referred to as the "Sea Gypsies" (although the term has been used to encompass a number of non-related ethnic groups with similar traditional lifestyles, such as the Orang Laut of southeastern Sumatra and the Riau Islands of Indonesia).

The various Bajau sub-groups vary culturally, linguistically, and religiously. Religion can vary from a strict adherence to sunni-islam to animistic beliefs in spirits and ancestor worship. Traditional Bajau communities may have a dukun (i.e. a shaman) and may adhere to taboos concerning the treatment of the sea and other cultural aspects. An example of this is the offering of thanks to the "embo dilaut", the God of the Sea, whenever a particularly large catch is brought in. The east coast Sabah Bajau are also famous for the annual "Semporna Regatta". Among the boat-dwellers in particular, community spirit mediums are consulted at least once a year for a public seance and nightly trance dancing. In times of epidemics, the mediums are also called upon to remove illness causing spirits from the community. They do this by setting a "spirit boat" adrift in the open sea beyond the village or anchorage.

West Coast Bajaus are expert horsemen, the famous "Cowboys of the East". This is their main claim to fame in Malaysia, where horse riding has never been widespread anywhere else. During special occasions, the Bajau horsemen wear a black long-sleeved shirt (badu sampit) and trousers (seluar sampit) which have gold lace trimmings sewn on, together with a headpiece (podong), similar to the Bajau bridegroom. Gold buttons (betawi) run down the front opening of the shirt (which is sometimes white, instead of black) and decorated with silver flowers called intiras. The trousers are more tight-fitting than the bajau bridegroom's seluar sama, with a silver-hilted dagger (keris) inside a wood and silver sheath at his side. He also carries a spear (bujak) and a shipping crop (pasut). The Bajau horseman's horse (or rather pony) has its own costume and is more gaily dressed than the rider. The outfit (kain kuda) almost completely covers the pony, except for holes for its eyes and nose. This cloth is tied around the pony's legs to keep it in place. The saddle (sila-sila) is not like those of the cowboys of the West but is a smaller piece of buffalo hide, so shaped to fit the pony's back. A thick piece of cloth (lapik) is placed under the sila-sila. Antique brass bells (seriau), colorful reins (tingalu) and bridle (kakang) all make for a very festive pony costume.

Although the state of Sabah have begun to practice the 1Malaysia concept a long time ago through inter-ethnic marriage, but it cannot assure the survival of the future harmony. Furthermore, the inclusions of external cultural elements have some impact on the culture itself, especially for Bajau ethnic in Kota Belud. A long time ago, when a mother gives birth to her son, all the family members will gather for 7 days in the house. Not only the family members, but also the neighbors will come to join the ceremony which will be performed at night and guests will be served drinks and some cake or biscuits. Sometimes the ceremonies named "bertitik" which is accompanied by traditional instruments such as gongs; xylophone and drums were played to entertain the guests. However, this tradition is being eroded, and some of the people did not follow the "berjogo" culture anymore after childbirth, in spite of the fact that culture is a way to strengthen family ties. When the culture is not practiced, then it is difficult for the family members to meet up even during the festival. Thus, this attitude has somehow contributed to the breakdown of the family system which will trigger the attitude of individualistic where individuals are less sensitive to other people and ultimately it will affects interpersonal relationships.

\section{CONCEPT PREJUdice, STEREOTYPE AND DISCRIMINATION}

\section{A. Prejudice}

Prejudice is human's inner characteristic which is wrong and awkward, inner feelings ordered and phrase toward certain society group or only toward certain individual. McLemore [2] and Healey [3] defined prejudice as negative view about others ethnic or just towards a certain ethnic. Usually this perception does not come with clear information. When this prejudices is spoken out, it become stereotype. "Scapegoat" theory introduced by Dollard [4], explains that prejudice happen due to pre judgment, which does not refer to any real facts. In general, prejudice starts with the feeling of disappointment and this feeling is applied by a majority group or individual to bully the minority group. According to Simpson and Yinger [5], prejudice culture is conservative and it will constantly develop from time to time, such as attitude, values and belief. This mean that when someone hold an prejudice assumption as part of the "culture heritage", then the individual will always think and act negatively toward other groups.

\section{B. Stereotype}

According to McLemore [2] and Healey [3], stereotype refers to a negative general statement that speaks toward certain ethnic group. Stereotype will cause the ethnic to look down on others ethnics followed by limited interaction which can finally build up racism. There were two types of stereotype. First, is labeling which mean downgrading the minority group, such as "lazy" and "not smart". Secondly, it 
occurs when the differences of power and status between minority group and the dominant group become diminished. Minority group with almost same status with dominant group will cause the dominant group to act out negatively toward the progressing minority group and give statement like "too smart", "too tricky" and so on.

\section{Discrimination}

Discrimination are perception, thought and negative belief of someone or a group of ethnic toward others ethnic groups or members which will affect their behavior and negative perceptions. It is prejudice manifestation within an ethnic group. Shamsul Amri Baharudin, [6]. At this stage, discrimination can be interpreted by some group differently in term of act and the meaning of word. Discrimination is defined as unjustified negative behavior toward a particular social group and the members of that group. Indeed, past research has suggested that discrimination typically stems from prejudiced attitudes and stereotypes towards other groups (Dovidio, Kawakami, \& Gaertner, [7]. An experiment by Ziegert and Hanges [8] indicated that when given justification for discrimination by an authority in an organizational setting, individuals with higher levels of unconscious racial bias rated Black job applicants more negatively compared to those low in unconscious racial bias. Further, a study by Norton, Sommers, Vandello, and Darley [9] showed evidence that individuals will provide non-racial justifications for race-related selection decisions, and that this is especially true for individuals high on racial prejudice.

\section{OBJECTIVE}

The purpose of the study is to identify perception among government and private worker toward the ethnic of Bajau in Malaysia, especially in Sabah State.

\section{METHOD}

\section{A. Sample and Location}

A total of 22 workers from government and private agency were invited to join this study. In-depth interview had been used to investigate perception of Bajau towards own ethnic and perception of others ethnic toward Bajau.

\section{B. Data Analysis}

Data is analyzed with indigenous psychology approach by Braun and Clarke (2006) using categorization, open coding and axial coding method.

\section{RESUlT AND DiSCUSSION}

\section{A. Their Perception on Own}

From the attitude and behavior aspects, Bajau identify themselves as patient, like to help, does not care, introvert, envious person, not consolidating, no manners, against elderly, youngster like to drinks alcohol, hide their feeling, fight with cleaver (parang), fight to kill, competing with town area people, unwilling to help, good, help each other, respect, and elements of greed.

Bajau ethnic says their physical and appearance are similar to Timor Leste from Indonesia and Philippine and sometime mis-associated as Filipino due to their skin color. The Bajau's are skilled fishermen as well as good rice cultivators. That is why their claim themselves patient. Rice cultivation have a long processes. First is land preparation to have the soil in optimum physical condition for growing rice. Plowing and tilling of land is done to predetermined levels that allow rice plants to develop a good root system. The proper preparation of land for sowing is achieved via tractors (mechanical means) or with the help of water buffaloes. But nowadays, the tradition using a buffaloes has been disappeared especially in Kota Belud. The machine takeover because it's can be done in one day. Land preparation also includes leveling to ensure water reaches all areas planted. The good paddy is when their grow-up with green color. Many years ago, like others country, transplanting is the more popular plant establishment technique. Transplanting occurs when pre-germinated seedlings are transferred from a seedbed to the wet field. It requires less seed and is an effective method for controlling weeds. Nowadays, most of Bajau'S people especially in Kota belud direct seeding sown by hand or plated by machine. So the process easier and no need to transferred anymore. Harvesting is the process of collecting the mature rice crop from field. Depending on the variety, rice crop usually reached maturity at around 115-120 days after crop establishment. Harvesting can be performed manually or mechanically. Mostly by machine because it is can be done in couples of hour.

TABLE I: PERCEPTION OF BAJAU TOWARD THEIR OWN ETHNIC

\begin{tabular}{cc} 
Ethnic & Bajau \\
\hline $\begin{array}{c}\text { Attitude } \\
\text { and } \\
\text { behavior }\end{array}$ & $\begin{array}{c}\text { Patient (5), like to helps (4), don't care (4), introvert } \\
\text { (2), envious person (2), not consolidate (1), no } \\
\text { manners (1), against elderly (1), youngster like to } \\
\text { drinks alcohol (1), hide feeling (1), fight with } \\
\text { cleaver (1), fight must kill (1), competed with town } \\
\text { area peoples (1), unwilling to help (1), good (1), } \\
\text { help each other (1), respect (1), greed when meet (1) }\end{array}$ \\
\hline $\begin{array}{c}\text { Physical } \\
\text { and }\end{array}$ & $\begin{array}{c}\text { Look alike Timor (1), like Pilipino (3), face (2) } \\
\text { appearance }\end{array}$ \\
\hline Culture & $\begin{array}{c}\text { Set aside (2), Tradition disappear slowly (1), } \\
\text { conversation (1), language (2), fisherman (2) }\end{array}$ \\
\hline
\end{tabular}

See Table I, they are also experts in rearing ponies and water buffaloes. Dubbed "the Cowboys of the East" they are renowned for their horsemanship. In their culture aspect, it is reported that their culture are residing away. One of the interviewee said Bajau traditions are disappearing slowly. This is because some of the tradition does not apply ceremonies such as "bejogo" and "seliuh anymore. The "seliuh" tradition only happens when the Bajau communities start harvesting their Paddy. They take turns to make their job easier. Nowadays all the activities are being replaced by machine and work now can be done in just one day. Bajau ethnic are also known by their conversation style and language. Bajau language from Kota Belud district is 
different from Tuaran, Papar and also Semporna in Tawau. The rhythm of language from Papar area is softer compared to Kota Belud and Tuaran. Meanwhile Bajau communities from Semporna speak a different language compare to kota belud, tuaran and papar. Although bajau community from Semporna claims themselves as Bajau but their languages totally difference with Bajau from West coast of Sabah. This is because Semporna District is near to Philippine country so their languages more too Filipino style.

Below were some of the statement from interviewee:

"maybe tradision disapear from day to day, traditions Bajau had disappear", "also like fighting ", "...this ethnic bajau for now I see from day to day, teenagers like us now, most of them, like to drink so much, drink alcohol. Bajau's teenagers same age like us against elderly, "If Bajau, they tend to outspoken and dare to die also a little bit rude." "We same Bajau always help each other”, “...this Bajau easier to fight by using parang until kill! U know?”

\section{B. Perception toward Bajau}

How about others ethnic are perceptions toward Bajau? The opinions from others ethnic such as Chinese, kadazandusun, murut and melayu brunei toward Bajau in term of attitude and behavior aspect is that Bajau is rude (behavior, words, and when get angry). Most of Bajau people talk loudly especially the elderly besides outspoken. Their also pleasant, not good at work, like to monopoly business, dawdle, quiet, good natured, good in trading, not controlling of their children, cooperative, straight forward, discuss directly, outspoken, does not care much of education, like to fight and dare to die. When their said this ethnic not controlling of their children, bajau's people seem like to be independence.

According to the one of our interviewee Bajau people like to fight because of their past generation. This statement of course does not include all Bajau ethnic. Some time they fight in order to protect friends and their spirit of ethnicity become more powerful. In terms of physical and appearance, others ethnic report that the Bajau ethnic if not of beauty and has a dark skin tone. Furthermore, in term of culture aspect, Bajau have their own language and dialect, low education level, and discourages their ethnic to marry Bajau ethnic due to Bajau's culture (See Table II).

TABLE II: OTHERS ETHNIC GROUPS PERCEPTION TOWARD ETHNIC BAJAU

Ethnic

BAJAU

Not good at work (1), like to monopoly business (1), dawdle (1), Rude (6), quiet (1), pleasant (2), good (1), like Attitude and business (1), not control their children (1), can co-operate behavior (1), straight forward (1), discuss directly (1), outspoken (1), rude words (1), don't care about study (1), like to fight (1), dare to die (1)

$\begin{gathered}\text { Physical and } \\ \text { appearance }\end{gathered}$
$\begin{gathered}\text { Less of beauty (2), low education level (2), don't marry } \\ \text { with Bajau (2), dark ski n (4) }\end{gathered}$

dialect(2), language(1)

Culture

Below were some of the statement from interviewee:
“Their look like Filipino, that's why people think this ethnic a little bit rude..their also like fighting and don't ever try to argue with them ortherwise you can be killed by them..", "their like to monoply in business but cheated..", "their also very cooperative to others", "a litte bit rude".

Comparing from the own perception and also others ethnic perception towards bajau, there are several finding has matched such as bajau like to fight, dark skin and also like to monopoly in business.

\section{CONCLUSION}

Overall, we can concluded that the understanding from others ethnic groups toward Bajau is on the lesser side, but there are some of the factors that match the perception of Bajau toward themselves, such as Bajau is or rude natured. This might be due to the less understanding from others ethnic or the disappearing traditional culture of Bajau. This result is an in-depth interview from government and private workers which shows that most of the workers identify an ethnic through the ethnic's slang and language. This happens in every country, where a race will have difference dialect and the people will also differentiate them from the slang they used (Mior Ahmad, Mior Hamzah \& Rashidah Mamat, [10]). This study only focuses on the perception from some government and private workers. This is one of the limitations in the study. In the future study, it should be include the perceptions from other levels of people in the society. This will help increasing the understanding of others toward Bajau, and at the same time decreasing the misunderstanding among all the ethnic groups. The prejudice among ethnic should be focus in next research because this factor can be a triggered in future especially in countries that have many ethnic. Nowadays, a conflict between ethnic has been occurred in some country in the world. The communities should be aware that small matter can be a trigger if there is no effort from now on.

\section{REFERENCES}

[1] Z. Aziz, A. Salleh, and D. H. E. Ribu, "A Study of National Integration," Procedia Social and Behavioral Science, vol. 7, pp. 691-700, 2010.

[2] S. D. M. Lemore, Racial, Ethnic Relations in America, $7^{\text {th }}$ Ed., Boston, Mass: Pearson/Ally and Bacon, 1994, pp. 124.

[3] J. F. Healey, Race, Ethnicity, Gender and Class: The Sociology of Group conflict and Change, $5^{\text {th }}$ ed., Newport: Christopher Newport University, 2009, pp. 110.

[4] J. Dollard, N. E. Miller, L. Doob, O. H. Mowrer, and R. R. Sears, Frustration and Aggression, New Haven, CT: Yale University Press, pp. 337-342.

[5] G. E. Simpson and J. M. Yinger, Closed Doors, Opportunities Lost: The Cost of Housing Discrimination, New York: Sage, 1985, pp. 107-108.

[6] S. A. Baharudin, Modul Hubungan Etnik Kuala Lumpur, Mashka Sdn.Bhd, 2007, pp. 12.

[7] J. F. Dovidio, K. Kawakami, and S. L. Gaertner, "Implicit and explicit prejudice and interracial interaction," Journal of Personality and Social Psychology, vol. 82, pp. 62-68, 2002.

[8] J. C. Ziegert and P. J. Hanges, "Employment discrimination: The role of implicit attitudes, motivation, and a climate for racial bias," Journal of Applied Psychology, vol. 90, pp. 553-562, 2005.

[9] M. I. Norton, S. R. Sommers, J. A. Vandello, and J. M. Darley, "Mixed motives and racial bias: The impact of legitimate and illegitimate 
criteria on decision making," Psychology, Public Policy, and Law, vol. 12, pp. 36-55, 2006.

[10] M. Hamzah, M. Ahmad, and M. Rashidah, "Nilai Perpaduan dan Kenegaraan Malaysia: Mencari Titik Persamaan dari kepelbagaian Komuniti Pasca Modenisme," Seminar Antarabangsa Nilai dalam Komuniti Pasca Modenisme (SIVIC, 2004), pp. 4-6, 2004.

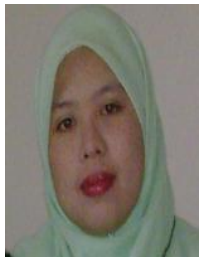

Lailawati Binti Madlan was born on 20 March 1975 She obtaibed her Bachelor of Education (Guidance and Counseling) from the State University of Semarang, Central Java, Indonesia (2001), Master of Psychology (2006) from University Malaysia Sabah (UMS) and PhD (in progress) at University Malaysia Sabah.

Currently, she works as a lecturer in Universiti Malaysia Sabah. She published many articles, such as
1) "Stress and Coping among University students: A preliminary research on ethnicity," Southeast Asia Psychology Journal, vol 1. 2) Hubungan antara stress dan sumber stress di kalangan pelajar university. Jurnal Kebajikan Masyarakat, vol. 36. 3) Stres dalam kalangan guru: satu perbandingan antara Bandar dan luar Bandar. UPPsiKs: UMS, 2011.

Mrs. Lailawati's membership is in Asian Association in social psychology (AASP), Malaysian Psychology Association (PSIMA), and Malaysian social Science Association. 